\title{
Reclassification of Lactobacillus cellobiosus Rogosa et al. 1953 as a later synonym of Lactobacillus fermentum Beijerinck 1901
}

\author{
Franco Dellaglio, Sandra Torriani and Giovanna E. Felis \\ Dipartimento Scientifico e Tecnologico, Università degli Studi di Verona, 37134 Verona, Italy
}

Correspondence

Franco Dellaglio

franco.dellaglio@univr.it

\begin{abstract}
The name Lactobacillus cellobiosus is validly published, but the species is often neglected in taxonomic studies, due to its high similarity to Lactobacillus fermentum. In the present paper, literature data concerning the two species were reviewed. Phylogenetic placement of L. cellobiosus was obtained based on $16 \mathrm{~S}$ rDNA sequences, and genetic similarity was further investigated by comparing partial recA gene sequences for the type strains of $L$. cellobiosus and $L$. fermentum. Based on the high identity values for $16 \mathrm{~S}$ rDNA (99\%) and recA gene $(98 \%)$ sequences, the results of DNA-DNA hybridization assays and phenotypic traits available from the literature, it is proposed that $L$. cellobiosus be reclassified and, as a rule of priority, renamed as $L$. fermentum, the first described species.
\end{abstract}

The first description of Lactobacillus fermentum can be traced back to Beijerink (1901), as a heterofermentative Lactobacillus species which could be isolated from milk products, sourdough, fermenting plant material, manure, sewage and the mouth and faeces of man. Lactobacillus cellobiosus was first described by Rogosa et al. (1953) and is another heterofermentative Lactobacillus species. They share very similar phenotypic properties and both belong to the subgenus 'Betabacterium' Orla-Jensen of Lactobacillus.

Since the 1970s, strains belonging to L. cellobiosus and $L$. fermentum have been subjected to DNA-DNA hybridization studies, which proved their high relatedness (Vescovo et al., 1979). Despite the evidence that strains ATCC $11739^{\mathrm{T}}$ and ATCC 11740 of L. cellobiosus showed hybridization values higher than $70 \%$ with $L$. fermentum ATCC $14932^{\mathrm{T}}$, the two species were both included in the Approved List of Bacterial Names (Skerman et al., 1980). A later DNA-DNA hybridization study (Sriranganathan et al., 1985), in which the strains L. fermentum NCDO 215 and L. cellobiosus NCDO 927 were examined, confirmed the findings of Vescovo et al. (1979), but no reclassification was proposed. On the basis of DNA-relatedness data, Kandler \& Weiss (1989) reported L. cellobiosus as a biotype of L. fermentum in Bergey's Manual of Systematic Bacteriology. As a consequence, $L$. cellobiosus was omitted from the phylogenetic analysis of the genus Lactobacillus (Collins et al., 1991), and the $16 \mathrm{~S}$ rDNA sequence of $L$. cellobiosus has been deposited

The GenBank/EMBL/DDBJ accession numbers for the partial recA sequences of Lactobacillus cellobiosus and Lactobacillus fermentum are AJ579535 and AJ579534, respectively. only very recently, under the designation $L$. fermentum (AJ575812).

Considering other literature, it is clear that the treatment of L. cellobiosus is inconsistent. Pot et al. (1994) reported that the name L. cellobiosus was invalid, while Dellaglio et al. (1994) presented it as a taxon awaiting reclassification, and Hammes \& Vogel (1995) did not include it in a discussion of the Lactobacillus species. Nevertheless, no formal reclassification proposal has been presented so far, despite the availability of data supporting the close relationship between L. fermentum and L. cellobiosus. The latter name is validly published, as described in online taxonomic resources (List of Bacterial Names with Standing in Nomenclature, http://www.bacterio.cict.fr/; Bacterial Nomenclature Up-to-date, http://www.dsmz.de/bactnom/ bactname.htm).

Strain depositions in major culture collections further complicate the study of the status of the species L. cellobiosus. In the ATCC (http://www.atcc.org), only two strains are available, ATCC $11739^{\mathrm{T}}$ and ATCC 11740, but they are registered as 'Lactobacillus fermentum Beijerinck deposited as Lactobacillus cellobiosus Rogosa et al.'. In the DSMZ (http://www.dsmz.de), only strain DSM $20055^{\mathrm{T}}$ is available, with the comment 'pro synon., Lactobacillus fermentum, never formally stated'. The Belgian Co-ordinated Collections of Microorganisms, Bacteria Collection (BCCM/ LMG; http://www.belspo.be/bccm), has two strains, LMG $9846^{\mathrm{T}}$ and LMG 11441, corresponding to ATCC $11739^{\mathrm{T}}$ and ATCC 11740, respectively, with the former registered as L. cellobiosus and the latter as L. fermentum. Finally, in the Japan Collection of Microorganisms (JCM; http:// www.jcm.riken.go.jp/), four strains are available: JCM 1137, 
JCM 2766, JCM 2767 and JCM 2768 - all registered as L. fermentum.

In the present study, the phylogenetic placement of L. cellobiosus was determined by the analysis of the $16 \mathrm{~S}$ rDNA sequences available for the most closely related species. Moreover, for the type strains of L. fermentum and L. cellobiosus, partial sequences for the recA gene were obtained and compared to evaluate better the relatedness of the two species.

Lactobacillus fermentum LMG $6902^{\mathrm{T}}$ and L. cellobiosus DSM $20055^{\mathrm{T}}$ were grown in MRS at 37 and $30^{\circ} \mathrm{C}$, respectively. Cultures were checked for purity, and DNA was extracted by the procedure of Marmur (1961).

Small subunit (16S) rDNA sequences were aligned with the CLUSTAL X program (Thompson et al., 1997). Positions ambiguously aligned, not available or not identified ( $\mathrm{N}$ in the sequence) were removed from all the sequences. Phylogenetic analysis was performed on the remaining 1366 positions with the TREECON program (Van de Peer \& De Wachter, 1994) using Galtier and Gouy distance (Galtier \& Gouy, 1995). The phylogenetic tree inferred for the considered species is shown in Fig. 1. The close relationship of L. cellobiosus and L. fermentum is supported by sequence identity: the two strains share 1361 of $1366 \mathrm{bp}$, confirming the high genetic relatedness suggested by DNA-hybridization data (Vescovo et al., 1979).

Nevertheless, it is known that $16 \mathrm{~S}$ rDNA sequence identity is not sufficient to guarantee species identity (Fox et al.,
1992). Protein-coding genes show greater variability, and recA has proved particularly useful in the differentiation of closely related species with almost identical $16 \mathrm{~S}$ rDNA sequences, including lactic acid bacteria. Examples are Lactobacillus plantarum, Lactobacillus paraplantarum and Lactobacillus pentosus (Torriani et al., 2001), and Lactobacillus casei, Lactobacillus rhamnosus and Lactobacillus zeae (Felis et al., 2001). Accordingly, partial recA amplicons of about 730 bp were obtained by PCR with the degenerate primers recEXT-f ( $5^{\prime}$-GGC TAT GAA ACA AAT TGA AAA ACA ATW YGG NAA RGG-3') and recEXT1-r (5'-TGT TTA AAC GGT GGA GCA ACT TTR TTY TTN AC-3'). The PCR mixture $(50 \mu \mathrm{l})$ was composed of $1 \times$ reaction buffer, $2 \mathrm{mM}$ magnesium chloride, $100 \mu \mathrm{M}$ dNTPs, $1 \mu \mathrm{M}$ both primers, $0.08 \mathrm{U}$ Taq polymerase $\mu \mathrm{l}^{-1}, 5 \%(\mathrm{v} / \mathrm{v})$ DMSO and $300 \mathrm{ng}$ template DNA. After an initial denaturation of 5 min at $94{ }^{\circ} \mathrm{C}, 30$ cycles of $1 \mathrm{~min}$ at $94^{\circ} \mathrm{C}, 1 \mathrm{~min}$ at $50{ }^{\circ} \mathrm{C}$ and $1 \mathrm{~min}$ at $72^{\circ} \mathrm{C}$ were carried out. A final extension at $72{ }^{\circ} \mathrm{C}$ for 7 min was performed. Amplification products of the expected length of about $730 \mathrm{bp}$ were obtained from both type strains. Sequencing reactions were performed at the Biomolecular Research Centre at the University of Padua. Regions of primer annealing were removed and $659 \mathrm{bp}$ were used in further comparisons. A $98 \%$ DNA sequence similarity was obtained, confirming that the two type strains belong to the same taxon. Data previously obtained for the L. casei species group (Felis et al., 2001) suggest that $r e c A$-sequence variability within a single Lactobacillus species is very low; therefore, we assumed that similarity values obtained for the type strains of $L$. cellobiosus and $L$. fermentum can be extended to all strains belonging to the two species.

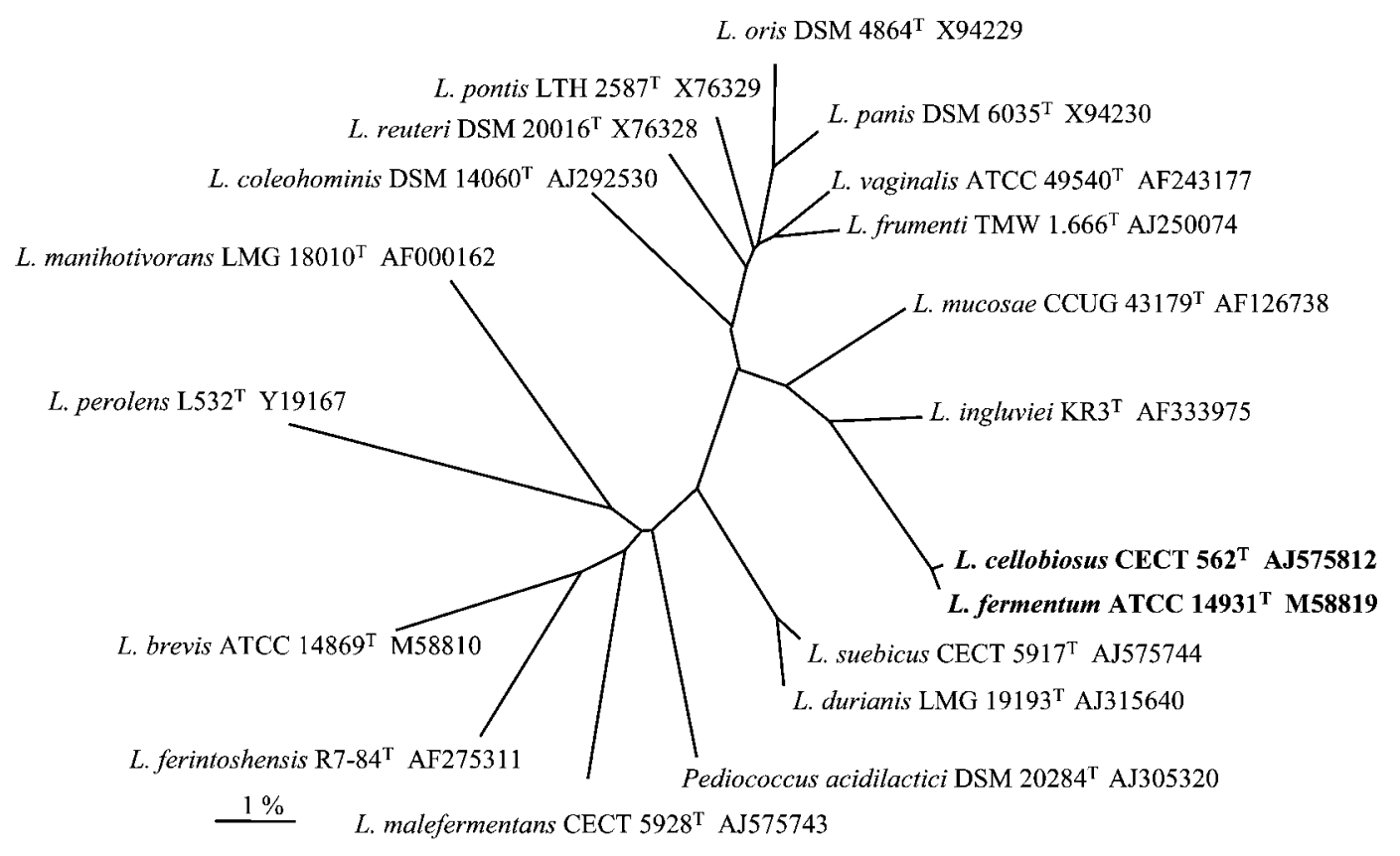

Fig. 1. Phylogenetic tree for Lactobacillus species, based on partial $16 \mathrm{~S}$ rDNA sequences. Bar, $1 \%$ sequence divergence. 
Table 1. Phenotypic traits that differentiate strains of $L$. fermentum and $L$. cellobiosus

Data reported from Rogosa et al. (1953), Rogosa \& Hansen (1971) and Dellaglio et al. (1994). V, Variable.

\begin{tabular}{|lcc|}
\hline Characteristic & \multicolumn{2}{c|}{ Species } \\
\cline { 2 - 3 } & L. cellobiosus & L. fermentum \\
\hline Growth at: & $\mathrm{V}$ & - \\
$15{ }^{\circ} \mathrm{C}$ & - & + \\
$45^{\circ} \mathrm{C}$ & & \\
Fermentation of: & + & - \\
Aesculin & $\mathrm{V}$ & - \\
Amygdalin & + & $\mathrm{V}$ \\
Arabinose & + & + \\
Cellobiose & $\mathrm{V}$ & - \\
Melibiose & \pm & + \\
Salicin & - & - \\
Trehalose & Glycerol & $\mathrm{L}$ \\
Teichoic acid type & $\mathrm{L}$ or DL & \\
Lactic acid isomer & & \\
\hline
\end{tabular}

Despite the high genetic relatedness, literature data (Rogosa et al., 1953; Rogosa \& Hansen, 1971; Dellaglio et al., 1994) suggest that the two taxa differ in several phenotypic traits, as shown in Table 1. This heterogeneity could be an indication of an infraspecific subdivision, which was not deepened due to the unclear attribution and scarcity of strains in culture collections, as explained above.

Based on the reviewed data and the additional results presented in this paper, it is proposed that L. cellobiosus and $L$. fermentum be united under the same name; as a rule of priority (Rules 38 and 42 of the Bacteriological Code; Lapage et al., 1992), the name L. fermentum is the earlier synonym and the name $L$. cellobiosus is the later synonym.

\section{Emended description of Lactobacillus fermentum Beijerinck 1901}

Cells are rods, $0 \cdot 5-0.9 \mu \mathrm{m}$ thick and highly variable in length, occurring singly or in pairs. Heterofermentative strains; they ferment fructose, galactose, glucose, gluconate, lactose, maltose, mannose, melibiose, raffinose, ribose and sucrose. No acid is produced from mannitol, melezitose, rhamnose, salicin or sorbitol. Some strains may produce acid from amygdalin, arabinose, cellobiose, aesculin, trehalose and xylose. Genome G+C content is $52-54 \mathrm{~mol} \%$. They produce L- or DL-lactic acid and $\mathrm{NH}_{3}$ from arginine, and may grow at 15 or $45^{\circ} \mathrm{C}$. Isolated from milk products, sourdough, fermenting plant material, manure, sewage and human mouth and faeces.

The type strain is ATCC $14931^{\mathrm{T}}\left(=\mathrm{DSM} 20052^{\mathrm{T}}=\mathrm{NCDO}\right.$ $1750^{\mathrm{T}}=$ LMG $6902^{\mathrm{T}}$ ).

\section{Acknowledgements}

We are grateful to Professor M. Vescovo for kindly providing old literature.

\section{References}

Beijerink, M. W. (1901). Sur les ferments lactiques de l'industrie. Arch Néerl Sci Exactes Nat Série II 7, 212-243.

Collins, M. D., Rodrigues, U. M., Ash, C., Aguirre, M., Farrow, J. A. E., Martinez-Murcia, A., Phillips, B. A., Williams, A. M. \& Wallbanks, S. (1991). Phylogenetic analysis of the genus Lactobacillus and related lactic acid bacteria as determined by reverse transcriptase sequencing of 16S rRNA. FEMS Microbiol Lett 77, 5-12.

Dellaglio, F., de Roissart, H., Torriani, S., Curk, M. C. \& Janssens, D. (1994). Caractéristiques générales des bactéries lactiques, In Bactéries Lactiques, vol. I, pp. 25-116. Edited by H. de Roissart \& F. M. Luquet. Uriage, France: Lorica.

Felis, G. E., Dellaglio, F., Mizzi, L. \& Torriani, S. (2001). Comparative sequence analysis of a $r e c A$ gene fragment brings new evidence for a change in the taxonomy of the Lactobacillus casei group. Int J Syst Evol Microbiol 51, 2113-2117.

Fox, G. E., Wisotzkey, J. D. \& Jurtshuk, P, Jr. (1992). How close is close: $16 \mathrm{~S}$ rRNA sequence identity may not be sufficient to guarantee species identity. Int J Syst Bacteriol 42, 166-170.

Galtier, N. \& Gouy, M. (1995). Inferring phylogenies from DNA sequences of unequal base compositions. Proc Natl Acad Sci U S A 92, 11317-11321.

Hammes, W. P. \& Vogel, R. F. (1995). The genus Lactobacillus. In The Genera of Lactic Acid Bacteria, vol. 2, pp. 19-54. Edited by B. J. B. Wood \& W. H. Holzapfel. Glasgow: Blackie Academic \& Professional.

Kandler, O. \& Weiss, N. (1989). Regular, nonsporeforming, Grampositive rods. In Bergey's Manual of Systematic Bacteriology, vol. 2, pp. 1208-1234. Edited by P. H. A. Sneath, N. S. Mair, M. E. Sharpe \& J. G. Holt. Baltimore: Williams \& Wilkins.

Skerman, V. B. D., McGowan, V. \& Sneath, P. H. A. (editors) (1980). Approved lists of bacterial names. Int J Syst Bacteriol 30, 225-420.

Lapage, S. P., Sneath, P. H. A., Lessel, E. F., Skerman, V. B. D., Seelinger, H. P. R. \& Clark, W. A. (editors) (1992). International Code of Nomenclature of Bacteria (1990 Revision). Bacteriological Code. Washington, DC: American Society for Microbiology.

Marmur, J. (1961). A procedure for the isolation of DNA from microorganisms. J Mol Biol 3, 208-218.

Pot, B., Ludwig, W., Kersters, K. \& Schleifer, K.-H. (1994). Taxonomy of lactic acid bacteria. In Bacteriocins of Lactic Acid Bacteria: Microbiology, Genetics \& Applications, pp. 13-90. Edited by L. De Vuyst \& E. J. Vandamme. London: Blackie Academic \& Professional.

Rogosa, M. \& Hansen, P. A. (1971). Nomenclatural consideration of certain species of Lactobacillus Beijerinck. Request for an opinion. Int J Syst Bacteriol 21, 177-186.

Rogosa, M., Wiseman, R. F., Mitchell, J. A., Disraely, M. N. \& Beaman, A. J. (1953). Species differentiation of oral lactobacilli from man including descriptions of Lactobacillus salivarius nov. spec. and Lactobacillus cellobiosus nov. spec. J Bacteriol 65, 681-699.

Sriranganathan, N., Seidler, R. J. \& Sandine, W. E. (1985). Nucleic acids of species of Lactobacillus. J Dairy Sci 68, 1077-1086.

Thompson, J. D., Gibson, T. J., Plewniak, F., Jeanmougin, F. \& Higgins, D. G. (1997). The ClUSTAL $X$ windows interface: flexible strategies for multiple sequence alignment aided by quality analysis tools. Nucleic Acids Res 24, 4876-4882. 
Torriani, S., Felis, G. E. \& Dellaglio, F. (2001). Differentiation of Lactobacillus plantarum, L. pentosus, and L. paraplantarum by recA gene sequence analysis and multiplex PCR assay with $r e c A$ genederived primers. Appl Environ Microbiol 67, 3450-3454.

Van de Peer, Y. \& De Wachter, R. (1994). TREECON for Windows: a software package for the construction and drawing of evolutionary trees for the Microsoft Windows environment. Comput Appl Biosci 10, 569-570.

Vescovo, M., Dellaglio, F., Bottazzi, V. \& Sarra, P. G. (1979). Deoxyribonucleic acid homology among Lactobacillus species of the subgenus Betabacterium Orla-Jensen. Microbiologica 2, $317-330$. 